CZASOPISMO INŻYNIERII LA¿DOWEJ, ŚRODOWISKA I ARCHITEKTURY JOURNAL OF CIVIL ENGINEERING, ENVIRONMENT AND ARCHITECTURE

JCEEA, t. XXXIII, z. 63 (4/16), październik-grudzień 2016, s. 61-70

Dorota A. CHWIEDUK ${ }^{1}$

Michał W. CHWIEDUK ${ }^{2}$

\title{
WYBRANE ASPEKTY TWORZENIA CHARAKTERYSTYKI ENERGETYCZNEJ BUDYNKU NISKOENERGETYCZNEGO
}

\begin{abstract}
W artykule przedstawiono wybrane wyniki obliczeń charakterystyki energetycznej budynku niskoenergetycznego zlokalizowanego w okolicach Warszawy. Wybrany do rozważań budynek jest budynkiem jednorodzinnym, w którym zastosowano rozwiązania mające na celu zmniejszenie zapotrzebowania na ciepło do ogrzewania pomieszczeń i zmniejszenie zużycia energii końcowej oraz pierwotnej do celów grzewczych. Budynek nie wymaga chłodzenia, ze względu na odpowiednią bryłę i strukturę oraz elementy zacieniające. Rozważania odnoszą się do części charakterystyki energetycznej budynku dotyczącej ogrzewania budynku i przedstawiają, jak znacznie mogą różnić się wskaźniki energochłonności w zależności od pochodzenia danych (teoretycznych - standardowych lub rzeczywistych - eksploatacyjnych) wykorzystywanych do wyznaczenia charakterystyki. Niestety obowiązująca metodyka obliczeniowa uniemożliwia uwzględnienie wszystkich rzeczywistych warunków eksploatacyjnych, zwłaszcza tych niekonwencjonalnych, co jest istotą tworzenia budownictwa niskoenergetycznego, a tym bardziej samowystarczalnego. Co więcej również samo wyznaczenie zapotrzebowania na energię użytkową także uniemożliwia uwzględnienie istotnych rozwiązań strukturalnomateriałowych budynku wpływających na rzeczywiste zmniejszenie zapotrzebowania na energię. Wskaźnik całkowitego zużycia energii pierwotnej dla analizowanego budynku, uzyskany na podstawie rzeczywistych danych (łącznie z zapotrzebowaniem na ciepło do c.w.u.) wyniósł $24,9 \mathrm{kWh} /\left(\mathrm{m}^{2}\right.$ rok $)$, natomiast na podstawie danych teoretycznych $48,54 \mathrm{kWh} /\left(\mathrm{m}^{2} \mathrm{rok}\right)$. Oba wyniki wskazują na niskie zużycie energii w budynku, jednak wartości te różnią się dwukrotnie, chociaż dotyczą tego samego budynku. Zaleca się więc w przypadku budynków niskoenergetycznych wykorzystywania rzeczywistych danych eksploatacyjnych budynku.
\end{abstract}

Słowa kluczowe: budownictwo niskoenergetyczne, certyfikacja energetyczna budynków, charakterystyka energetyczna budynku, budownictwo energooszczędne, odnawialne źródła energii

1 Autor do korespondencji / corresponding author: Dorota Anna Chwieduk, Politechnika Warszawska, Instytut Techniki Cieplnej, Zakład Chłodnictwa i Energetyki Budynku, ul. Nowowiejska 21/25, 00-665 Warszawa; tel. 2223452 27; dchwied@itc.pw.edu.pl

2 Michał Witold Chwieduk, Politechnika Warszawska, Instytut Techniki Cieplnej, Zakład Chłodnictwa i Energetyki Budynku, ul. Nowowiejska 21/25, 00-665 Warszawa; mchwied@itc.pw.edu.pl 


\section{Wprowadzenie}

W krajach Unii Europejskiej sektor budownictwa cechuje wysoka energochłonność. Komisja Europejska podjęła szereg działań na rzecz ograniczenia zużycia energii w budynkach. W 2002 roku weszła w życie Dyrektywa Parlamentu Europejskiego i Rady Europy w sprawie charakterystyki energetycznej budynków [1], która zobowiązała państwa UE do wprowadzenia certyfikacji energetyczne budynków. W Polsce świadectwa charakterystyki energetycznej budynków zostały wprowadzone z dniem 1 stycznia 2009 roku. Metodyka sporządzania charakterystyki została określona w Rozporządzeniu Ministra Infrastruktury [2] w 2008 r., a następnie zmieniona Rozporządzeniem [3] z 2015 roku. Zmiana ta była konsekwencją nowelizacji Dyrektywy w sprawie charakterystyki energetycznej budynków z 2010 roku [4], która zobowiązała kraje UE do realizacji budynków blisko-zero-energetycznych.

Niniejszy artykuł ma na celu przedstawienie wybranych aspektów wyznaczania, zgodnie z obecnie obowiązującymi zasadami, charakterystyki energetycznej budynku niskoenergetycznego wykorzystującego odnawialne źródła energii.

\section{Charakterystyka ogólna budynku i jego instalacji}

Budynek poddany ocenie energetycznej, zlokalizowany pod Warszawą, jest pokazany na rys. 1 . Posiada on dwie kondygnacje użytkowe: parter i piętro oraz nieużytkowe poddasze. Budynek ma prostą zwartą bryłę, główna fasada przeszklona jest od strony południowej. Budynek jest rozciągnięty wzdłuż osi wschód - zachód na długości 17 metrów, a wzdłuż osi południe - północ 11 metrów. Od północy znajdują się pomieszczenia nieogrzewane - zimne: garaż, „,kotłownia”, spiżarnia oraz pomieszczenie gospodarcze. Od południa znajduje się przeszklona „słoneczna” przestrzeń buforowa, wbudowana w budynek, której przeszklenie wraz z pozostałymi oknami stanowi około $70 \%$ powierzchni południowej fasady. Wbudowana przeszklona przestrzeń buforowa jest bardzo istotnym elementem nowoczesnych rozwiązań budownictwa słonecznego niskoenergetycznego [5]. Powierzchnia ogrzewana budynku wynosi $360 \mathrm{~m}^{2}$.

Ściany zewnętrzne budynku zostały wykonane z pustaka ceramicznego o grubości $25 \mathrm{~cm}$, są izolowane wełną mineralną o grubości $20 \mathrm{lub} 25 \mathrm{~cm}$, i pokryte tynkiem mineralnym. Współczynnik przenikania ścian zewnętrznych wynosi $0,14 \mathrm{~W} /\left(\mathrm{m}^{2} \mathrm{~K}\right)$. Dach jest dwuspadowy o konstrukcji drewnianej, połaciach zorientowanych na północ i południe, pochylonych pod kątem $38^{\circ}$, pokryty dachówką cementową. W budynku zastosowano stropy ceramiczne (Teriva) o grubość $26,5 \mathrm{~cm}$. Na poddaszu są one izolowane wełną mineralną o grubości $25 \mathrm{~cm}$ na paroizolacji, ich współczynnik przenikania ciepła wynosi $0,19 \mathrm{~W} /\left(\mathrm{m}^{2} \mathrm{~K}\right)$. Podłoga na gruncie jest izolowana, współczynnik przenikania to $0,21 \mathrm{~W} /\left(\mathrm{m}^{2} \mathrm{~K}\right)$. Natomiast współczynnik przenikania okien wynosi $1,40 \mathrm{~W} /\left(\mathrm{m}^{2} \mathrm{~K}\right)$. 


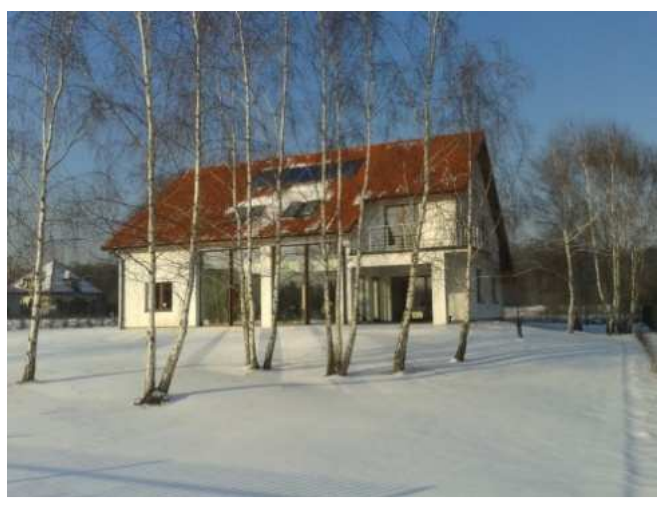

Rys.1. Rozważany niskoenergetyczny budynek jednorodzinny $\mathrm{k} /$ Warszawy

Fig. 1. Considered low-energy single family building located near Warsaw

Należy wspomnieć, że koncepcja architektoniczno - budowlana budynku została szczegółowo opracowana przez autorkę artykułu, a projekt wykonawczy powstał w wyniku jej współpracy z architektem. Koncepcja ta nie jest przedmiotem rozważań w tym artykule. Stosowanie obowiązującej metody obliczenia charakterystyki energetycznej budynku uniemożliwia uwzględnienie wszystkich niekonwencjonalnych rozwiązań koncepcji architektonicznej budynku, oraz rozwiązań strukturalnych i materiałowych. W tym przypadku dotyczy to przede wszystkim koncepcji słonecznej przeszklonej przestrzeni buforowej wbudowanej w budynek, oraz zastosowania materiałów zmienno-fazowych PCM wkomponowanych $\mathrm{w}$ materiał budowlany przegród nieprzezroczystych ograniczających przestrzeń buforową.

Do podstawowych rozwiązań instalacyjnych budynku należą:

- grzewcza instalacja kolektorów słonecznych typu kombi (c.w.u. + ogrzewanie pomieszczeń) współpracująca z pompą ciepła, kolektory słoneczne o powierzchni czynnej 10,92 $\mathrm{m}^{2}$ zintegrowane $\mathrm{z}$ połacią dachu, system słoneczny działa cały rok, od kwietnia do października spełnia $85-100 \%$ potrzeb c.w.u.;

- zasobnik ciepła buforowy - pojemność 7001 , zasilany ciepłem z pompy ciepła i kolektorów, zasobnik ciepłej wody użytkowej - pojemność 150 1;

- gruntowa pompa ciepła - podstawowe źródło ciepła o mocy grzewczej 8,2 kW z gruntowym wymiennikiem ciepła -4 odwierty pionowe o głębokości 50m każdy; pompa ciepła nie działa poza sezonem ogrzewczym;

- wentylacja nawiewno-wywiewna $\mathrm{z}$ rekuperatorem ciepła o zmiennej wydajności $300-900 \mathrm{~m}^{3} / \mathrm{godz}$, o efektywności odzysku ciepła z powietrza wywiewanego na poziomie $70 \%$, instalacja jest wykorzystywana w sezonie grzewczym;

- instalacja niskotemperaturowego wodnego ogrzewania podłogowego. 
W budynku jest także kominek z zamkniętą komorą spalania $\mathrm{z}$ doprowadzeniem powietrza $\mathrm{z}$ zewnątrz do paleniska, który jest dodatkowym źródłem ciepła służącym do ogrzewania pomieszczeń (nie został on uwzględniany w obliczeniach). Dodatkowym źródłem ciepła wynikającym z odpowiedniego wykorzystania zysków z promieniowania słonecznego jest ,przeszklona wbudowana przestrzeń buforowa", z otwieranymi przeszkleniami - oknami. Przestrzeń ta jest co prawda uwzględniona w obliczeniach charakterystyki, ale obowiązująca metodyka obliczeń uniemożliwia wyznaczenie rzeczywistych zysków ciepła. Przede wszystkim w przypadku stosowania takiej przestrzeni konieczne jest prowadzenie rozważań odnośnie do procesów wymiany ciepła z krokiem godzinowym, a nie uśrednionym do jednego dnia, czy miesiąca, a taka metoda obowiązuje. Co więcej idea stosowania przestrzeni buforowej wbudowanej w budynek polega na wprowadzeniu do wewnętrznej użytkowej części budynku przestrzeni, która jest ograniczona przegrodami przezroczystymi (tutaj z trzech stron), co oznacza stosowanie dwóch dwuszybowych okien w odniesieniu do głównej części mieszkalnej budynku (przestrzeń buforowa jest wykorzystywana, głównie w porach przejściowych, ale nie tylko). Stosowanie takiego rozwiązania ma miejsce wtedy, gdy zachodzi konieczność ograniczenia strat ciepła z budynku (zimą), jak i zmniejszenia dostępu promieniowania słonecznego (latem), dzięki zmniejszeniu transmisyjności dla promieniowania słonecznego. W przypadku rozważanej przestrzeni część przeszkleń zewnętrznych i wszystkie wewnętrzne są otwierane. Jeżeli wykorzystanie zysków słonecznych jest ważne w celu zmniejszenia zapotrzebowania na ciepło do ogrzewania, wtedy wewnętrzny układ przeszkleń jest (powinien być) otwarty. Z kolei otwieranie zewnętrznej części chroni przed nadmiarem zysków słonecznych. Niestety metodyka wyznaczania charakterystyki nie uwzględnia możliwości zmiany parametrów cieplnych i optycznych obudowy w czasie, a w konsekwencji zmiany w czasie współczynników strat cieplnych i zysków, co coraz częściej charakteryzuje budownictwo niskoenergetycznego.

\section{Zapotrzebowanie na ciepło do celów ogrzewczych}

W tej części zestawiono wyniki obliczeń współczynników przenikania ciepła dla kolejnych przegród ocenianego budynku (tabela 1), strat wentylacyjnych i zysków ciepła. Następnie przedstawiono miesięczne zapotrzebowanie na ciepło do ogrzewania pomieszczeń. Całkowity współczynnik strat ciepła przez przenikanie wyniósł 220,15 W/K. Natomiast współczynnika strat ciepła w przypadku wentylacji nawiewno-wywiewnej z rekuperacją wyniósł 29,55 W/K. Gdyby zastosowano wentylację grawitacyjną współczynnik ten wyniósłby 98,5 W/K. Przy obliczaniu współczynników wentylacyjnych uwzględniono strumienie powietrza wymagane ze względów higienicznych oraz dostające się do pomieszczeń na skutek infiltracji (brak próby szczelności). Wewnętrzne zyski ciepła są stałe w czasie i wynoszą $27,7 \mathrm{kWh} /$ dzień. Powierzchnie okien i ich orientacja wzglę- 
dem stron świata są podane w tabeli 1 . Tabela 2 zawiera miesięczne zyski słoneczne, współczynnik wykorzystania tych zysków i liczbę godzin sezonu grzewczego.

Tabela 1. Współczynnik przenikania ciepła i powierzchnie przegród obudowy

Table 1. Heat transfer coefficients and surfaces of partitions of envelope

\begin{tabular}{|c|c|c|}
\hline Rodzaj przegrody & $\begin{array}{c}\mathbf{U} \\
{\left[\mathbf{W} /\left(\mathbf{m}^{2} \mathbf{K}\right)\right]}\end{array}$ & $\begin{array}{c}\text { A S/N/W/E } \\
{\left[\mathrm{m}^{2}\right]}\end{array}$ \\
\hline ściany zewnętrzne - konstrukcyjne & 0,14 & $21,28 / 0 / 55,6 / 51,3$ \\
\hline $\begin{array}{l}\text { strop nad pierwszym piętrem (pod poddaszem nieo- } \\
\text { grzewanym) }\end{array}$ & 0,12 & 126,7 \\
\hline ściana oddzielająca garaż od części ogrzewanej & 0,25 & $0 / 24,87 / 0 / 0$ \\
\hline $\begin{array}{l}\text { ściana oddzielająca spiżarnie oraz pomieszczenie go- } \\
\text { spodarcze od części ogrzewanej }\end{array}$ & 0,28 & $0 / 19,13 / 0 / 0$ \\
\hline ściana oddzielająca „kotłownię” od części ogrzewanej & 1,15 & $0 / 22,25 / 0 / 0$ \\
\hline dach - obliczenia metodą kresu górnego i dolnego & 0,19 & $35,89 / 51,70 /$ \\
\hline podłoga na gruncie (wartość ekwiwalentna) & 0,17 & 189,42 \\
\hline stolarka okienna & $1,2 / 1,4$ & $\begin{array}{c}42,8+4,4^{*} / 0+2,1^{*} / \\
8,4 / 18,32\end{array}$ \\
\hline
\end{tabular}

Uwaga. W Tabeli nie uwzględniono przegród zewnętrznych pomieszczeń nieogrzewanych i mostków cieplnych (w obliczeniach tak)

Tabela 2. Sumaryczne zyski słoneczne Qs [kWh/miesiąc], współczynnik wykorzystania zysków słonecznych $\mathrm{f}_{\mathrm{H}, \mathrm{m}}$, liczba godzin grzewczych $\mathrm{t}_{\mathrm{M}} \mathrm{w}$ kolejnych miesiącach roku

Table 2. Summary solar gains Qs [kWh/month], utilization of solar energy gains factor $\mathrm{f}_{\mathrm{H}, \mathrm{m}}$, number of heating hours $t_{M}$ in subsequent months

\begin{tabular}{|c|c|c|c|c|c|c|c|c|c|c|c|c|}
\hline Msc & I & II & III & IV & V & VI & VII & VIII & IX & X & XI & XII \\
\hline $\mathrm{Q}_{\mathrm{s}}$ & 1386 & 1522 & 2738 & 3508 & 4655 & 4818 & 4963 & 4493 & 3094 & 1980 & 968 & 809 \\
\hline $\mathrm{f}_{\mathrm{H}, \mathrm{m}}$ & 1 & 1 & 0,14 & - & - & - & - & - & - & 0,11 & 1 & 1 \\
\hline $\mathrm{t}_{\mathrm{M}}$ & 744 & 672 & 105,6 & - & - & - & - & - & - & 83,1 & 720 & 744 \\
\hline
\end{tabular}

Dość istotnym parametrem budynku, choć ciągle niedocenianym, jest stała czasowa. Jest ona miernikiem jakości energetycznej budynku, będąc zależna od jego izolacyjności cieplnej (oporności cieplnej), efektywności systemu wentylacji (w tym przypadku z rekuperacją ciepła), a także pojemności cieplnej $\left(\mathrm{C}_{\mathrm{m}}=178045 \mathrm{~kJ} / \mathrm{K}\right)$. Stała ta wynosi 196 godzin, jest bardzo wysoka i świadczy o wysokiej jakości cieplnej budynku, czyli małym zapotrzebowaniu na ciepło do c.o.

W Tabeli 3 zestawiono sumaryczne miesięczne straty ciepła przez przenikanie i wentylację (z rekuperacją) i zyski ciepła wewnętrzne oraz z promieniowania słonecznego. Po wyznaczeniu współczynników efektywności wykorzystania zysków ciepła obliczono zapotrzebowanie na ciepło do ogrzewania.

Jak można zauważyć zapotrzebowanie na moc grzewczą w marcu i październiku jest na minimalnym poziomie. System ogrzewania praktycznie nie pracuje w tym czasie, co rzeczywiście potwierdza eksploatacja systemu ogrzew- 
czego. Sezon ogrzewczy trwa nieco ponad cztery miesiące Roczne zapotrzebowanie ciepła użytkowego dla budynku ocenianego wynosi $5671,22 \mathrm{kWh}$. Gdyby w rozważanym budynku nie było wentylacji z rekuperacją wtedy roczne zapotrzebowanie na ciepło wynosiłoby aż 9972,06 kWh.

Tabela 3 Miesięczne sumaryczne straty ciepła przez przenikanie i wentylację dla budynku $\mathrm{QH}, \mathrm{ht}$, sumaryczne zyski ciepła $\mathrm{QH}_{\text {,gn }}$, zapotrzebowanie na ciepło do ogrzewania $\mathrm{QH}_{\text {,nd,n }}$

Table 3. The monthly summary heat losses by transmission and ventilation for the building $\mathrm{QH}$,ht, summary heat losses $\mathrm{QH}_{\mathrm{gn}}$, heat demand for heating $\mathrm{QH}, \mathrm{nd}, \mathrm{n}$

\begin{tabular}{|c|c|c|c|c|c|c|}
\hline & I & II & III & IV & V & VI \\
\hline $\mathrm{Q}_{\mathrm{H}, \mathrm{ht}}$ & 3827 & 3406 & 2787 & 2355 & 1338 & 413 \\
\hline $\mathrm{Q}_{\mathrm{H}, \mathrm{gn}}$ & 2245 & 2298 & 3598 & 4339 & 5515 & 5650 \\
\hline $\mathrm{Q}_{\mathrm{H}, \mathrm{nd}, \mathrm{n}}$ & 1582 & 1111 & 17 & - & - & - \\
\hline & VII & VIII & IX & $\mathbf{X}$ & $\mathbf{X I}$ & $\mathbf{X I I}$ \\
\hline $\mathrm{Q}_{\mathrm{H}, \mathrm{ht}}$ & 37 & 520 & 1186 & 2081 & 2966 & 3455 \\
\hline $\mathrm{Q}_{\mathrm{H}, \mathrm{gn}}$ & 5822 & 5353 & 3926 & 2839 & 1800 & 1668 \\
\hline $\mathrm{Q}_{\mathrm{H}, \mathrm{nd}, \mathrm{n}}$ & - & - & - & 6,8 & 1167 & 1787 \\
\hline
\end{tabular}

\section{Zapotrzebowanie na energię końcową i pierwotną do celów ogrzewczych}

Aby wyznaczyć zapotrzebowanie na energię końcową do celów ogrzewczych należy określić średnią sezonowa sprawność całkowitą systemu ogrzewania, na którą składają się średnie sezonowe sprawności: wytwarzania ciepła z energii dostarczanej do źródła ciepła, regulacji i wykorzystania ciepła w przestrzeni ogrzewanej, przesyłu ciepła ze źródła ciepła do przestrzeni ogrzewanej oraz sprawność akumulacji ciepła w elementach pojemnościowych systemu ogrzewczego.

Wartość średniej sezonowej sprawności wytwarzania ciepła przyjmuje się w oparciu o dane zamieszczone w odpowiedniej tabeli w Rozporządzeniu [3] lub dane udostępnione przez producenta lub dostawcę źródła ciepła, jeśli w budynku są przeprowadzone kontrole okresowe, polegające na sprawdzeniu ich stanu technicznego. W przypadku stosowania sprężarkowej (napędzanej elektrycznie) pompy ciepła typu glikol/woda (parametry obiegu ogrzewczego $35 / 28^{\circ} \mathrm{C}$ ), wg odpowiedniej tabeli wspomnianą sprawność (tak naprawdę efektywność) należałoby przyjąć jako równą 4. Jednakże dzięki posiadaniu danych z kontroli okresowej można ją przyjąć jako równą 4,9 , a to istotna różnica.

$\mathrm{W}$ rozważanym budynku zastosowano ogrzewanie wodne podłogowe $\mathrm{z}$ regulacją centralną i miejscową z regulatorem proporcjonalnym. Na podstawie odpowiedniej tabeli z Rozporządzenia [3] przyjęto średnią sezonową sprawność regulacji i wykorzystania ciepła w przestrzeni ogrzewanej równą 0,89 .

Przy wyznaczaniu średniej sezonowej sprawności przesyłu ciepła ze źródła ciepła do przestrzeni ogrzewanej określa się sezonowe straty ciepła w systemie 
ogrzewczym w wyniku niedoskonałej regulacji i przekazywania ciepła, i w rozważanym przypadku wynoszą one $700,94 \mathrm{kWh} /$ rok. Następnie wyznacza się sezonowe straty ciepła $\mathrm{w}$ instalacji przesyłu ciepła. Uwzględnia się rzeczywistą długość kolejnych odcinków instalacji przesyłu ciepła i dodatek do długości ze względu na straty ciepła zainstalowanej armatury, oraz przyjmuje się wartości jednostkowej straty ciepła kolejnych odcinków instalacji przesyłu ciepła na podstawie danych stabelaryzowanych [3]. W rozważanym przypadku w przestrzeni nieogrzewanej zastępcza długość instalacji przesyłu równa się 4,5 m, a jednostkowe straty ciepła odpowiadają $2,1 \mathrm{~W} / \mathrm{m}$. Natomiast w przestrzeni ogrzewanej zastępcza długość instalacji przesyłu wynosi $11,5 \mathrm{~m}$, a straty jednostkowe $1,1 \mathrm{~W} / \mathrm{m}$. Biorąc pod uwagę czas trwania sezonu ogrzewczego - 3000 godz., całkowite sezonowe straty ciepła $w$ instalacji przesyłu ciepła wynoszą zaledwie $66,3 \mathrm{kWh} / \mathrm{rok}$. Ostatecznie obliczona średnia sezonowa sprawności przesyłu ciepła ze źródła ciepła do przestrzeni ogrzewanej budynku wynosi 0,99. Gdyby nie było danych do obliczeń wtedy wg danych tabelarycznych [3] średnia sezonowa sprawności przesyłu ciepła wynosiłaby 0,96 .

W celu określenia średniej sezonowej sprawności akumulacji ciepła w elementach pojemnościowych systemu ogrzewania należy wyznaczyć sezonowe straty ciepła $\mathrm{w}$ elementach pojemnościowych tego systemu i uwzględnić czas pracy instalacji ogrzewania. W rozważanym przypadku pojemność zasobnika ciepła wynosi 700 litrów i jest on zlokalizowany w nieogrzewanej przestrzeni. Jednostkowa strata ciepła zasobnika ciepła przyjęta na podstawie odpowiedniej tabeli [3] wynosi $0,2 \mathrm{~W} / \mathrm{dm}^{3}$. Natomiast czas pracy instalacji ogrzewania wynosi 3000 godz. W konsekwencji sezonowe straty ciepła w elementach pojemnościowych systemu ogrzewania wynoszą $420 \mathrm{kWh} / \mathrm{rok}$, a odpowiadająca im średnia sezonowa sprawność akumulacji ciepła odpowiada 0,94 . W przypadku braku danych do obliczeń przyjęta wartość średniej sezonowej sprawności akumulacji ciepła wg odpowiedniej tabeli [3] wynosiłaby 0,93 .

Uwzględniając wszystkie składowe sprawności/efektywności średnia sezonowa sprawność całkowita systemu ogrzewczego wynosi 4,06. W konsekwencji roczne zapotrzebowanie na energię końcową dostarczaną do budynku dla systemu ogrzewania wynosi 1396,85 kWh/rok. Biorąc pod uwagę dane teoretyczne stabelaryzowane w Rozporządzeniu [3] zapotrzebowanie to wynosiłoby $2405,46 \mathrm{kWh} /$ rok, co jest 1,8 razy większe od rzeczywistego zużycia, co stanowi istotną różnicę w energochłonności instalacji ogrzewczej danego budynku.

Kolejne istotne różnice pomiędzy teoretycznym a rzeczywistym zużyciem energii występują przy wyznaczaniu zapotrzebowania na moc elektryczną do napędu urządzeń pomocniczych w systemach technicznych oraz czasu działania urządzeń pomocniczych w systemach technicznych w ciągu roku. W rozważanym budynku system ogrzewania działa okresowo i czas działania urządzeń pomocniczych przyjęto na podstawie rzeczywistego sposobu ich działania. W systemie ogrzewania z grzejnikami podłogowymi pracuje jedna pompa obiegowa o mocy $60 \mathrm{~W}$ przez 3000 godzin w ciągu. W konsekwencji roczne zapotrzebo- 
wanie na energię końcową dostarczaną do tej pompy wynosi $180 \mathrm{kWh} /$ rok. Pompa ładująca zasobnik ciepła w systemie ogrzewania ma również moc $60 \mathrm{~W}$, ale pracuje przez 1600 godzin w roku, jej roczne zapotrzebowanie na energię końcową wynosi $96 \mathrm{kWh} /$ rok. Pompa obiegowa w obiegu dolnego źródła ciepła pompy ciepła ma taką samą moc i pracuje przez taki sam czas, w konsekwencji energia końcowa wynosi również $96 \mathrm{kWh} /$ rok. Ostatecznie roczne zapotrzebowanie na energię końcową dostarczaną do wymienionych urządzeń pomocniczych wynosi zaledwie $372 \mathrm{kWh} /$ rok. Gdyby nie był znany rzeczywisty sposób działania instalacji wtedy na podstawie danych odczytanych $\mathrm{z}$ odpowiednich tabel [3] energia końcowa do napędu urządzeń pomocniczych w systemie ogrzewania wynosiłaby $1682,1 \mathrm{kWh} / \mathrm{rok}$, czyli byłaby aż cztery i pół razy większa. Sytuacja taka wynika z tego, iż korzystając z danych z Rozporządzenia czas działania niektórych urządzeń pomocniczych w systemach technicznych jest inny niż ten znany z rzeczywistej pracy tych urządzeń. Jest on zdecydowanie większy w przypadku pompy obiegowej instalacji ogrzewania podłogowego. Należy go bowiem przyjąć jako równy 6700 godzin, podczas gdy w rzeczywistości wynosi 3000 godzin. Natomiast w dolnym obiegu pompy ciepła czas pracy pompy obiegowej jest taki sam, a pompa ładująca zasobnik ciepła pracuje przez 1500 godzin. Podstawowa różnica wynika z konieczności stosowania wartości mocy pomp obiegowych w odniesieniu do powierzchni ogrzewanych pomieszczeń, która wynosi dla pomp obiegowych w systemie ogrzewania $\mathrm{z}$ grzejnikami podłogowymi $0,5 \mathrm{~W} / \mathrm{m}^{2}$ (przy wspomnianym czasie pracy równym $6700 \mathrm{~h} / \mathrm{rok}$ ), dla pompy ładującej zasobnik ciepła $0,2 \mathrm{~W} / \mathrm{m}^{2}$ (czas pracy $1500 \mathrm{~h} /$ rok), dla napędu pomocniczego pompy ciepła glikol/woda $0,45 \mathrm{~W} / \mathrm{m}^{2}$ (czas pracy $1600 \mathrm{~h} /$ rok).

W powyższych rozważaniach nie uwzględniono energii pomocniczej wymaganej do napędu urządzeń pomocniczych systemu wentylacji mechanicznej z rekuperacją, co niestety znacznie zmienia poziom zużycia energii pomocniczej. W rozważanym budynku w obiegu systemu rekuperacji pracują dwa wentylatory o mocy $250 \mathrm{~W}$ każdy. Ich teoretyczny czas pracy wynosi 3000 godzin. W rzeczywistości jest on mniejszy i wynosi 1500 godzin, bowiem instalacja nie pracuje w ciągu dnia przez 8 godzin (brak mieszkańców w domu) i przez 4 godziny w nocy. Energia elektryczna wymagana do napędu wynosi $780 \mathrm{kWh}$ (przy 3000 godzinach pracy byłoby to $1560 \mathrm{kWh}$ ). Gdyby skorzystać z danych stabelaryzowanych wtedy należy przyjąć zapotrzebowanie mocy elektrycznej do napędu każdego $\mathrm{z}$ wentylatorów na poziomie $0,6 \mathrm{~W} / \mathrm{m}^{2}$ (powierzchni ogrzewanej i czas pracy równy 3000 godzin. Energia do napędu urządzeń pomocniczych wentylatorów wynosiłaby wtedy $1296 \mathrm{kWh}$.

Ostatecznie roczne zapotrzebowanie na energię końcową dostarczaną do budynku dla systemów ogrzewania wraz z zapotrzebowaniem na energię końcową urządzeń pomocniczych, w tym wentylatorów instalacji wentylacji wymuszonej z rekuperacją, wynosi: $1396,85+372+780=2548,85 \mathrm{kWh} /$ rok. Gdyby wziąć pod uwagę wszystkie dane teoretyczne, wtedy zapotrzebowanie na ener- 
gię końcową dla tego samego systemu ogrzewania rozważanego budynku wynosiłoby: $2405,46+1682,1+1296=5383,56 \mathrm{kWh} / \mathrm{rok}$. Co jest ponad dwukrotnie wyższą wartością. Pomimo to, wskaźnik zużycia energii końcowej (w odniesieniu do ogrzewanej powierzchni) jest na bardzo niskim poziomie i wynosi odpowiednio dla danych rzeczywistych $7,08 \mathrm{kWh} /\left(\mathrm{m}^{2} \mathrm{rok}\right)$ i dla danych teoretycznych i $14,95 \mathrm{kWh} /\left(\mathrm{m}^{2}\right.$ rok $)$. Gdyby nie zastosowano wentylacji wymuszonej z rekuperacją wtedy zużycie energii pomocniczej wynosiłoby $372 \mathrm{kWh} /$ rok wg danych rzeczywistych i 1682,1 kWh/rok wg danych teoretycznych. Natomiast wskaźniki energochłonności wynosiłyby $7,85 \mathrm{kWh} /\left(\mathrm{m}^{2}\right.$ rok $)$ i $16,42 \mathrm{kWh} /\left(\mathrm{m}^{2}\right.$ rok $)$.

$\mathrm{Z}$ kolei roczne zapotrzebowanie na nieodnawialną energię pierwotną dla systemów technicznych ogrzewania pomieszczeń, biorąc pod uwagę współczynnik nakładu nieodnawialnej energii pierwotnej dla energii elektrycznej równy 3, wynosi odpowiednio 7646,55 kWh dla danych rzeczywistych i $16150,68 \mathrm{kWh}$ dla teoretycznych, co daje wskaźniki zużycia energii pierwotnej odpowiednio $21,24 \mathrm{kWh} /\left(\mathrm{m}^{2}\right.$ rok $)$ i $44,86 \mathrm{kWh} /\left(\mathrm{m}^{2}\right.$ rok $)$. Przy braku systemu wentylacji z rekuperacją wskaźniki te byłyby równe $23,55 \mathrm{kWh} /\left(\mathrm{m}^{2}\right.$ rok $)$ oraz $49,26 \mathrm{kWh} /\left(\mathrm{m}^{2}\right.$ rok).

\section{Podsumowanie}

Uwzględniając roczne zapotrzebowanie budynku na energię pierwotną do podgrzewania c.w.u. (nie rozważane w tym artykule) równe $1324,79 \mathrm{kWh} / \mathrm{rok}$, wskaźniki całkowitego zużycia energii pierwotnej będą równe odpowiednio $24,9 \mathrm{kWh} /\left(\mathrm{m}^{2} \mathrm{rok}\right)$ i $48,54 \mathrm{kWh} /\left(\mathrm{m}^{2}\right.$ rok $)$. Pierwszy wskaźnik wyraźnie wskazuje na budynek niskoenergetyczny, drugi na budynek o zmniejszonym zapotrzebowaniu na energię, ale nie tak ,dobry energetycznie”, jak ten pierwszy. Jest to wyraźna różnica klasy energetycznej budynku. Co oczywiście nie jest prawdą, bowiem oba wskaźniki dotyczą tego samego budynku, a różnice wynikają z różnych danych przyjętych do wyznaczenia wskaźników energochłonności.

Wartość zapotrzebowania na nieodnawialną energię pierwotną dla systemów technicznych ogrzewania pomieszczeń obliczone wg danych z Rozporządzenia w analizowanym budynku to $44,86 \mathrm{kWh} /\left(\mathrm{m}^{2}\right.$ rok). Wartość obliczona $\mathrm{w}$ analogiczny sposób dla obiektu $\mathrm{z}$ wentylacją grawitacyjną wyniesie $49,26 \mathrm{kWh} /\left(\mathrm{m}^{2}\right.$ rok $)$. W związku z tym mogłoby wynikać, że stosowanie wentylacji z rekuperacją daje nieznaczne zmniejszenie energochłonności. Taki wniosek wynika przede wszystkim z wysokich wartości zapotrzebowania na energię pomocniczą do napędu wentylatorów, przy wykorzystaniu danych podanych w Rozporządzeniu. Dodatkowym czynnikiem, którego efektem są otrzymane wartości jest bardzo wysoka efektywność działania pompy ciepła, a w rezultacie średnia sezonowa sprawność całkowita systemu ogrzewczego równa 4,06. W przypadku innych źródeł ciepła korzyści ze stosowania rekuperacji będą bardziej wyraźne.

Rozważając przeprowadzone obliczenia można stwierdzić, iż w przypadku budynków niskoenergetycznych należy wykorzystywać rzeczywiste dane eksploatacyjne systemów energetycznych budynku przy tworzeniu jego charakterystyki 
energetycznej. Jednocześnie stosowana metodyka nie odzwierciedla w odpowiedni sposób jakości energetycznej budynków niskoenergetycznych. Rozważany budynek wykorzystuje energię odnawialne dla potrzeb cieplnych, a energia elektryczna (napędowa) pochodzi z tradycyjnych nieodnawialnych źródeł. Gdyby można było wykorzystać energię odnawialną do wytwarzania energii elektrycznej wskaźniki energochłonności powinny ulec dalszemu zmniejszeniu.

\title{
Literatura
}

[1] Dyrektywa 2002/91/WE Parlamentu Europejskiego i Rady z dnia 16 grudnia 2002 r. w sprawie charakterystyki energetycznej budynków.

[2] Rozporządzenie Ministra Infrastruktury z dnia 6 listopada 2008 r. w sprawie metodologii obliczania charakterystyki energetycznej budynku oraz sposobu sporządzania i wzorów świadectw ich charakterystyki energetycznej. (Dz.U. 2008 nr 201 poz. 1240).

[3] Rozporządzenie Ministra Infrastruktury i Rozwoju z dnia 27 lutego 2015 r. w sprawie metodologii wyznaczania charakterystyki energetycznej budynku oraz świadectw charakterystyki energetycznej (Dz.U. 2015 poz. 376).

[4] Dyrektywa Parlamentu Europejskiego i Rady 2010/31/UE z dnia 19 maja 2010 r. w sprawie charakterystyki energetycznej budynków.

[5] Chwieduk D, Energetyka Słoneczna Budynku. Arkady, Warszawa, 2011.

\section{SOME ASPECTS OF DETERMINATION THE ENERGY CHARACTERISTICS OF LOW ENERGY BUILDINGS}

\begin{abstract}
S u m m a r y
The article presents selected results of calculations the energy performance of low energy building located near Warsaw. In the selected building solutions aimed at reducing the energy needs for space heating and demand for final and primary energy consumption are introduced. Considerations apply to the part of the energy performance characteristic of the building connected with space heating only. Results show, how much may the indices of energy consumption depend on the origin of the data (theoretical - standard or real - in-situ) used to determine the characteristics. Unfortunately actual methodology of calculation makes it impossible to cover all real operating conditions, especially these unconventional, what is the essence of creating low-energy buildings, and the more self-sufficient ones. Moreover, the determination of the demand for usable energy also makes it impossible to take into account relevant solutions of structure and materials used in a building. Total primary energy consumption for the building, obtained based on actual data (including domestic hot water demand) is $24.9 \mathrm{kWh} /\left(\mathrm{m}^{2} \mathrm{year}\right)$, and on the basis of theoretical data-48.54 $\mathrm{kWh} /\left(\mathrm{m}^{2}\right.$ year $)$. Both results indicate a low energy consumption in the building, but these values differ twice. It is therefore recommended in a case of a low energy building to use actual in-situ data of the building.
\end{abstract}

Keywords: Low-energy buildings, energy certification of buildings, energy performance of the building, energy efficiency in buildings, renewable energy sources

DOI: $10.7862 / \mathrm{rb} .2016 .248$

Przestano do redakcji: $31.05 .2016 r$.

Przyjęto do druku: 20.12.2016 r. 